\title{
ISO 26000 Constructs In Malaysian Automotive Suppliers: Exploratory And Confirmatory Factor Analysis
}

\author{
Nursyazwani Mohd Fuzia*, Nurul Fadly Habidin ${ }^{b}$, Farah Izzaida Mohd Zamria, Siti Norhafizan Hibadullaha, Auni Fatin Nadia Chiek \\ Desa $^{a}$ \\ ${ }^{a}$ Departments of Accounting and Finance, Faculty of Management and Economics, Universiti Pendidikan Sultan Idris, 35900 Tanjung Malim, Perak, \\ Malaysia \\ ${ }^{b}$ Department of Management and Leadership, Faculty of Management and Economics, Universiti Pendidikan Sultan Idris, 35900 Tanjung Malim, Perak, \\ Malaysia
}

*Corresponding author: nursyazwanimohdfuzi@yahoo.com

\begin{abstract}
s
The purpose of this study is to examine ISO 26000 constructs in Malaysian automotive suppliers by using exploratory factor analysis and confirmatory factor analysis. ISO 26000 provides a guideline for businesses and organizations to operate in a socially responsible way. The demand for ISO 26000 is required for the automotive suppliers, as many car manufacturers require their suppliers to obtain it, particularly for Malaysian automotive suppliers. This research reviews the ISO 26000 literature and proposed two constructs with the recognizing social responsibility and stakeholder identification and engagement. 288 sets of questionnaire were successfully collected which showed $72 \%$ response rate from 400 set of questionnaires were distributed to top management of Proton and Perodua automotive suppliers. This paper presents finding of exploratory factor analysis (EFA) and confirmatory factor analysis (CFA) empirically verified and validated. The results indicate that two constructs are acceptable for further analysis.
\end{abstract}

Keywords: ISO 26000; recognizing social responsibility; stakeholder identification and engagement; exploratory factor analysis; confirmatory factor analysis; automotive suppliers.

\section{Abstrak}

Tujuan kajian ini adalah untuk mengkaji konstruk ISO 26000 dalam pembekal automotif di Malaysia dengan menggunakan analisis faktor eksploratori dan faktor pengesahan. ISO 26000 menyediakan garis panduan bagi perniagaan dan organisasi untuk beroperasi dengan cara yang bertanggungjawab secara sosial. Permintaan untuk ISO 26000 diperlukan dalam pembekal automotif kerana banyak pengeluar kereta memerlukan pembekal untuk mendapatkan bekalan, terutamanya bagi pembekal automotif di Malaysia. Kajian ini mengkaji kesusasteraan ISO 26000 dan mencadangkan dua konstruk dengan mengiktiraf tanggungjawab sosial dan pengenalan serta penglibatan pihak berkepentingan. 288 set soal selidik telah berjaya dikumpulkan yang menunjukkan $72 \%$ kadar maklum balas daripada 400 set soal selidik telah diedarkan kepada pengurusan tertinggi pembekal automotif Proton dan Perodua. Kertas kerja ini membentangkan dapatan Analisis Faktor Eksploratori (EFA) dan Analisis Faktor Pengesahan (CFA) disahkan secara empirik. Keputusan menunjukkan bahawa dua konstruk boleh diterima untuk analisis selanjutnya.

Kata Kunci: ISO 26000, mengiktiraf tanggungjawab sosial, pengenalan dan penglibatan pihak berkepentingan, analisis faktor eksploratori, analisis faktor pengesahan, pembekal automotif

(C) 2016 Penerbit UTM Press. All rights reserved

\subsection{INTRODUCTION}

The automotive industry plays a vital role in developing and expanding support to suppliers in order to enhance production and automotive manufacturing. Recently, Malaysian automotive industry has been a major manufacturer and exporter of vehicle spare parts, components, and accessories in the region. Besides, the automotive industry has reached capacity and efficiency in the design of components for original equipment and replacement markets (Hibadullah et al., 2013; Habidin et al., 2013, Fuzi et al., 2015). However, by enhancing globalization under ASEAN Free Trade Area (AFTA) and World Trade Organization (WTO), the government has faced an increasingly strong pressure to liberalize Malaysian automotive suppliers. Therefore, to reduce the failure of the quality initiative, one of the NAP objectives needs to be achieved which is to promote the competitiveness of the local industry including national car production, particularly for Malaysian automotive suppliers.

The National Automotive Policy (NAP) aims to implement optimal transformation and integration of national industry in the regional and global industry network. For this research purpose, the six objectives of the NAP 2014 are to encourage the competition in the local industry including national car, make Malaysia the regional hub in Energy Efficient Vehicles (EEV), promote value-added activities, improve the exports of vehicles and auto components, encourage the participation of Bumiputera companies in the domestic auto industry, and safeguard customer's interest by offering better quality products (MITI, 2014; Hibadullah et al., 2014). Based on that, NAP has 
reviewed the new investment, the long-term sustainability of the domestic automotive industry, ensuring quality of products, and environmental protection.

The International Standard ISO 26000 serves as a guideline on social responsibility which enables companies to comply with predetermines standards which promote the implementation of social responsibility among the stakeholders. Based on International Standard ISO 26000 (2010), it is the foundation of social responsibility to improve existing practice and meet the social responsibility in the organization. Thus, ISO 26000 is intended to encourage companies to comply with the laws and regulations related to social responsibility.

The demand for ISO 26000 is required for the automotive suppliers, as many car manufacturers require their suppliers to obtain it, particularly for Malaysian automotive suppliers. ISO 26000 provides a guideline for businesses and organizations to operate in a socially responsible way (Peloza \& Papania, 2008; Perera, 2009; Ecologia, 2011). However, as ISO 26000 is a new global initiative, there is still a lot for automotive suppliers to learn from the adoption and implementation of ISO 26000. A review of the literature identified a lack of study especially on the effects of ISO 26000 for Malaysian automotive suppliers (Huijstee \& Glasbergen, 2008; Castka \& Balzarova, 2007; Frost, 2009). By implementing ISO 26000, it can increase performance for Malaysian automotive suppliers in terms of saving costs, increasing profit and enhancing the quality of production.

Min (2010) explores the role of business ethics and social responsibility among Malaysian managers in relation to the implementation of ISO 26000. The findings show that there is still a lack of knowledge and experience in implementing tools to engage in social responsibility, especially any of the well-recommended social responsibility initiatives. Based on this study, a lack of awareness and method of engagement in social responsibility initiatives seemed to be the most significant obstacles in implementing ISO 26000 social responsibility engagement.

ISO 26000a should be concerned among Malaysian automotive suppliers. ISO 26000 provides a guideline for businesses and organizations to operate in a socially responsible way. However, as ISO 26000 is a new global initiative, there is still a lot to learn from the adoption and implementation of ISO 26000 (Castka \& Balzarova, 2007; Sully, 2012). A review of the literature identified a lack of study especially on the effects of ISO 26000 (Min, 2010; Hahn, 2012). Therefore, companies can implement ISO 26000 constructs as the guideline in order to enhance the performance for Malaysian automotive suppliers. The purpose of this study is to examine ISO 26000 constructs in Malaysian automotive suppliers by using the exploratory and confirmatory factor analysis.

The next section discusses the literature review, methodology, results and discussion, and finally, conclusions.

\subsection{LITERATURE REVIEW}

\section{ISO 26000}

International Organization for Standardization (ISO) has launched the ISO 26000 international standard on social responsibility. ISO 26000 standards is applicable to all organizations whether in the public sector or private sector. ISO 26000 provides guidance for businesses and organizations to operate in a socially responsible way.

Based on International Standard ISO 26000 (2010), it is the foundation of social responsibility to improve existing practices and meet the social responsibility in the organization. ISO 26000 is intended to encourage companies to comply with the laws and regulations related to social responsibility. Hence, ISO 26000 also considers the environmental, societal, cultural, and legal aspects to be implemented in the organization, particularly for Malaysian automotive suppliers.

Besides, ISO 26000 provides guidance for social responsibility among interest groups and encourage the implementation of CSR practices (Schwartz \& Tilling, 2009; Nisipeanu et al., 2011; Canada, 2012). ISO 26000 also provides guidelines on principles to integrate social responsibility in terms of strategies, systems, and processes which can be used by all types of organizations. By implementing ISO 26000 , the organization would be able to attract and retain employees or customers, commitment and productivity, identify the financial community, and increase relationship between customers and the communities in which it is operating (Greenwood, 2004; Frost, 2011; Vazquez \& White, 2012).

In addition, ISO 26000 provides guidelines on the reporting and stakeholders needs including the objectives and performance related to CSR practices. By adopting ISO 26000, this guideline assists the company in decision making by managing the company's performance in terms of improving social welfare, increase sales, and profits (Singh, 2009; Butler et al., 2011). At the same time, it can assist the company in increasing revenues or encouraging corporate strategies such as raising competitive advantage, enhancing customer satisfaction, and product quality. Hence, companies need to implement ISO 26000 as a benchmark of the organization in order to enhance the CSR practices for Malaysian automotive suppliers.

\section{Benefits of ISO 26000}

ISO 26000 is a tool for social responsibility to assist the organization to move with good action. All organizations can apply the ISO 26000 ISO 26000 is important for all organizations to adopt the guidance in order to improve the management system and activities related to social responsibility in improving the performance (McKelvey, 2007). This provides organizations with many positive outcomes such as increase relationships with stakeholders, improve financial community, and enhance competitive advantage of company.

By implementing ISO 26000, there are many benefits gained such as ensuring the safety and health of community, protect the environment, increase the company's policy, improve company's reputation, enhance the legal aspects, and standards of company (Roberts, 2010; Ward, 2012; Weber, 2012; Bustami et al., 2013). This is supported by Pojasek (2011) who suggested that ISO 26000 focuses on enhancing employee commitment, improving company's management, and providing decision-making and effective information. Table 1 shows the benefits of ISO 26000. 
Table 1 Benefits of ISO 26000

Benefits of ISO 26000

Encourage social goals, operate more efficiently and efficiency, increase the returns on capital investment, Roberts (2010)

enhance codes of conduct, and improve regulations and standards.

Ability to increase the values of the organization, reduce the risk of company, and increase quality and standard.

Hoivik (2011)

Provide social responsibility and accountability of the organization; enable organization in decision-making, monitoring practices on social responsibility, and increase social responsibility performance.

Provide social and environmental standards, enhance management practices, reducing business bias, and encourage involvement of stakeholders.

Ability to operate effectively, reduce corporate crisis, and enhance the company's profitability.

Pojasek (2011)

Balzarova and Castka (2012)

Moonsamy and Singh (2012)

Encourage organizations to comply with regulations, to promote social responsibility, and increase company's Kanokporn et al. (2013)

reputation with ethics.

Facilitate the organization for decision-making, enhance norms, values and beliefs on social responsibility, and Virtanen (2013) increase environmental laws and regulations.

\section{Measurement of ISO 26000 Constructs}

ISO 26000 constructs based on the fundamental practices of social responsibility and monitoring to assess the behavior and commitment. According to Kosi and Harazin (2011), ISO 26000 provides principles of social responsibility, two fundamental practices, and guidance on social responsibility core subjects. However, this study only focuses on two fundamental practices which are recognizing social responsibility and stakeholder identification and engagement.

\section{Recognizing Social Responsibility (RSR)}

Recognizing social responsibility (RSR) refers to the relationship between an organization, its stakeholder, and society. In Malaysian automotive suppliers, there should be RSR that can influence the decisions and activities of the organization. This is supported by Kelly (2009) who mentioned that ISO 26000 focuses on RSR to improve the company's decisions and activities as related to society and the environment.

International Standard ISO 26000 (2010) stated that organizations need to relate to the relationships in RSR; for example, the relationship between organizations and how organizations emphasize results and activities on the environment and society. Meanwhile, the relationship between stakeholders influences the decision of stakeholders in the organization's activities. Organizations also need to understand the relationship between societies which affect the stakeholders such as the interest of society. Thereby, RSR gives effect to the decision and activities of the organization.

\section{Stakeholder Identification and Engagement (SIE)}

ISO 26000 emphasizes SIE of social responsibility. For stakeholder identification is used to determine the location, scale, and nature of the operations for the stakeholders. Stakeholder identification refers to the interests of stakeholders may associated with social responsibility and give importance to the society (Zhang, 2012; Webb, 2012; Brown \& Forster, 2013). Furthermore, ISO 26000 performs as guidance for identifying stakeholders as the core company to undertake social responsibility. Thus, the impact of organizational decisions and activities allow organizations to identify stakeholders.

Based on study by Weinestedt (2009) and Merz (2011), stakeholder refers to any groups or individuals which affect the achievement of organizational objectives. It affects the decisions and activities of the organization to determine the stakeholders. In addition, stakeholders also closely related to social responsibility and provide benefits to the society (Sofia, 2010; Sedani \& Lakhe, 2011; Sully, 2012; Suntory, 2012). Hence, identification of stakeholder is vital for compliance with the law, operations, and financial so that it can assist the social responsibility of company.

The engagement of stakeholder involves one or more of the stakeholders for implementing organizational demands and make decisions to improve performance. Successful engagement of stakeholder assists organizations to develop, plan, and develop the business. In addition, Canada (2012) noted that the importance of stakeholder engagement is to share the information with stakeholders in improving the company's performance. It means that stakeholder engagement assists companies to make improvement in terms of environmental, social, and company policies.

Moreover, organizations need to adopt SIE to influence the organization and create sustainability in the company (Mainardes et al., 2011; Harrisson et al., 2012; Sitnikov \& Bocean, 2012; Bal et al., 2013). Therefore, effective SIE is based on good faith and goes beyond public relations. SIE can be used to increase the organization decision-making and activities on specific stakeholders, increase the beneficial impacts of decision and activities, determine whether social responsibility is trustworthy or not, improve the company's performance, fulfill legal obligation, conflict of interest, enhance transparency, and achieve mutually beneficial objective. 


\subsection{METHODOLOGY}

For this research purpose, the questionnaire was given simultaneously in each Proton and Perodua vendor by researcher. 288 sets of questionnaire were successfully collected which showed $72 \%$ response rate from 400 set of questionnaires were distributed to top management of Proton and Perodua automotive suppliers.

\section{Questionnaire Development}

In this study, the questionnaire consists of demographic information and ISO 26000 constructs. Table 2 shows the summary of survey questionnaire design. Based on previous studies, this questionnaire were adopted and adapted based on ISO 26000 constructs. ISO 26000 consist two constructs and the measurement items which are used for recognizing social responsibility are measured by five items, while the stakeholder identification and engagement has six items as shown in Table 3.

Table 2 Summary of survey questionnaire design

\begin{tabular}{cccc}
\hline Section & Topic & $\begin{array}{c}\text { No. of question, constructs and } \\
\text { items }\end{array}$ & Demographic Information/ Likert Scale \\
\hline 1 & Demographic Information & 8 questions & $\begin{array}{c}\text { Years in business, ownership, number of } \\
\text { employees, group of product, quality systems } \\
\text { certification, current position, period of } \\
\text { current position and quality award won. }\end{array}$ \\
2 & ISO 26000 & & $\begin{array}{c}7 \text { likert scale: } \\
\text { measurement items }\end{array}$ \\
\hline
\end{tabular}

Table 3 ISO 26000 constructs and measurement items

\begin{tabular}{|c|c|c|}
\hline ISO 26000 and Measurement Items & Adopted/ Adapted & Authors \\
\hline $\begin{array}{l}\text { Recognizing Social Responsibility } \\
\text { 1. Considering the issues of social responsibility. } \\
\text { 2. Recognition of its social responsibility. } \\
\text { 3. Relationship between an organization, its stakeholders and society. } \\
\text { 4. Understanding the social responsibility of an organization. } \\
\text { 5. Communication related to social responsibility. }\end{array}$ & Adopted & $\begin{array}{l}\text { Nisipeanu et al. } \\
\text { (2011); Kosi and } \\
\text { Harazin (2011) }\end{array}$ \\
\hline $\begin{array}{l}\text { Stakeholder Identification and Engagement } \\
\text { 1. Organizations identify stakeholders. } \\
\text { 2. Concerns about the decisions and activities of the organization. } \\
\text { 3. Organization's ability to meet its responsibilities. } \\
\text { 4. Guidance sets identifying and engaging with stakeholders. } \\
\text { 5. Stakeholder engagement reflects in corporate activities. } \\
\text { 6. Importance of the interests and expectations of different } \\
\text { stakeholders. }\end{array}$ & Adapted & $\begin{array}{l}\text { Mainardes et al. } \\
\text { (2011); Kosi and } \\
\text { Harazin (2011) }\end{array}$ \\
\hline
\end{tabular}

\section{Data Collection}

In this study, the population is focused on Proton and Perodua automotive suppliers. To achieve the objectives of this study, the samples were selected from the list of Proton and Perodua automotive suppliers. These lists of Proton and Perodua automotive suppliers consist of metal, plastic, rubber, electric, electronic, and other automotive parts.

The researcher visited the Proton and Perodua automotive suppliers in Shah Alam, Rawang, Bukit Beruntung, Tanjung Malim, Klang, and Nilai. The researcher chooses the respondents from the companies who held the top management position such as the Managing Director, Quality Control Manager, and the Manufacturing Manager about their practices and performance of the companies. For this research purpose, 400 questionnaires were given simultaneously in each Proton and Perodua automotive suppliers by researcher. 288 sets of questionnaire were successfully collected which showed $72 \%$ response rate from 400 set of questionnaires were distributed to Proton and Perodua automotive suppliers.

\section{Reliability and Validity Analysis}

Reliability is an important aspect of questionnaire design. The advantages of reliability include: each item is easy to be understood, each item is interpreted clearly, each item has a relationship with another item to achieve the goal of study and the item is accurate (Barrantes, 2012; Habidin 2012; Habidin \& Yusof, 2013). 
Reliability test is the most frequently used in empirical studies; the internal consistency is assessed using Cronbach's Coefficient Alpha. Cronbach's alpha provides a measure of the internal consistency of the test ranges between 0 and 1. According to Tavakol and Dennick (2011) and Hashim et al. (2012), the acceptable values of Cronbach alpha are from 0.70 to 0.90 .

Validity is defined as steps for measuring the instrument in the study. Drost (2011) mentioned that validity is very important to the research component for measuring validity of the test. These include construct validity, internal validity, and external validity (Abdullah et al., 2008; Jaya et al., 2012). The author states that internal validity is only used for explanatory or causal studies.

In this study, validation of the instrument was included in the following procedures: (i) content validity and (ii) construct validity. A construct is considered to have content validity measurement items which cover all important aspects of the constructs being measured (Zubir et al., 2012; Bottenfield, 2013). Thus, the validity of the representative samples can measure each item to reveal the instrument and elements of the concept in the study.

This study has used the Statistical Package for Social Sciences (SPSS) Version 21.0 software and Structural Equation Modeling (SEM) Version 20.0 to perform statistical analysis from data surveys.

SEM is a general statistical modeling technique which is widely used in social science. SEM is a multivariate technique for determining dependency relationship between the variables simultaneously. Multivariate technique as defined by Sweeney (2009) is a technique which combines aspects of factor analysis and multiple regression that permit researchers to examine a series of interrelated dependence relationship among the measured variables and latent constructs as well as between several latent constructs simultaneously. Multivariate technique as defined by Sweeney (2009) is a technique which combines aspects of factor analysis and multiple regression that permit researchers to examine a series of interrelated dependence relationship among the measured variables and latent constructs as well as between several latent constructs simultaneously.

For factor analysis in SEM, confirmatory factor analysis (CFA) and exploratory factor analysis (EFA) were used for the measurement model portion of SEM analysis. CFA is a statistical technique used to validate the variable factors. It is useful to test the hypothesis that relationship between observed variables with latent constructs is based on loading values (Hair et al., 2011). As for EFA, EFA is a variable reduction technique for identifying the number of latent constructs underlying a set of variables (Jain \& Shandliya, 2013; Hahn, 2012). EFA is to describe and identify the number of latent constructs such as unique factors and measurement errors in the data.

\section{Descriptive Statistics of Respondents}

Table 4 shows the descriptive statistics of respondents profile.

Table 4 Descriptive Statistics $(n=288)$

\begin{tabular}{|c|c|c|c|}
\hline Characteristics & Measurement & Frequency & Percentage \\
\hline \multirow[t]{3}{*}{ Types of ownership } & $100 \%$ local & 175 & 60.76 \\
\hline & $100 \%$ foreign & 36 & 12.50 \\
\hline & Joint venture & 77 & 26.74 \\
\hline \multirow[t]{3}{*}{ Number of year in business } & Less than 10 years & 53 & 18.40 \\
\hline & 10 to 20 years & 75 & 26.04 \\
\hline & More than 20 years & 160 & 55.56 \\
\hline \multicolumn{4}{|l|}{ Types of product manufactured ${ }^{1}$} \\
\hline & Metal & 120 & 41.67 \\
\hline & Plastic & 78 & 27.08 \\
\hline & Rubber & 20 & 6.94 \\
\hline & Engine/Transmission & 27 & 9.38 \\
\hline & Electric/Electronic & 30 & 10.42 \\
\hline & Others & 85 & 29.51 \\
\hline \multirow[t]{4}{*}{ Number of employee } & Less than 50 & 28 & 9.72 \\
\hline & Between 50 to 150 & 42 & 14.58 \\
\hline & Between 151 to 300 & 63 & 21.88 \\
\hline & More than 300 & 155 & 53.82 \\
\hline \multirow[t]{3}{*}{ Current position } & Senior management & 95 & 32.99 \\
\hline & Middle management & 165 & 57.29 \\
\hline & Others & 28 & 9.72 \\
\hline \multirow[t]{4}{*}{ Current position (years) } & Less than 1 year & 31 & 10.76 \\
\hline & 1 to 3 years & 53 & 18.40 \\
\hline & 3 to 6 years & 66 & 22.92 \\
\hline & More than 6 years & 138 & 47.92 \\
\hline \multirow{2}{*}{\multicolumn{4}{|c|}{$\begin{array}{l}\text { Company certified to quality system } \\
\text { standard }^{2}\end{array}$}} \\
\hline & ISO 9001:2008 & 82 & 28.47 \\
\hline & ISO TS 16949 & 228 & 79.17 \\
\hline & ISO 14001 & 147 & 51.04 \\
\hline & OHSAS 18001 & 56 & 19.44 \\
\hline & None & 8 & 2.78 \\
\hline & Others & 5 & 1.74 \\
\hline \multirow[t]{6}{*}{ Company have won quality award ${ }^{3}$} & Prime Minister's Quality Award & 1 & 0.35 \\
\hline & State Quality Award & 23 & 7.99 \\
\hline & Industrial Excellence Award & 64 & 22.22 \\
\hline & Quality Management Excellence & 45 & 15.63 \\
\hline & None & 146 & 50.69 \\
\hline & Others & 57 & 19.79 \\
\hline
\end{tabular}


1Note: Some companies have more than one product type

2Note: Some companies have more than one certification

3Note: Some companies have won more than one quality award

The respondents of this study were 288 managers from the companies of Proton and Perodua automotive suppliers. The descriptive statistics of the respondents $(n=288)$ is presented in Table 4.1. Firstly, the measure of demographic information is the types of ownership. Majority of the companies involved are fully owned by Malaysians $(60.76 \%), 12.50 \%$ is owned by foreigners, and followed by venture companies $(26.74 \%)$. Regarding the number of years in business, $55.56 \%$ had more than 20 years of business. This is followed by $26.04 \%$ that has been generating for $10-20$ years. Only $18.40 \%$ of them operated in less than 10 years.

The respondents come from companies with different types of products in the automotive suppliers. The types of product manufactured are categorized into six categories. They are metal, plastic, rubber, engine/transmission, electric/electronic, and others. Among six types of product, most companies manufactured metal with $41.67 \%$. This followed by plastic with $27.08 \%$. Rubber is the lowest types of product manufactured with percentage of $6.94 \%$.

The next survey was number of employees. $53.82 \%$ of the companies had more than 300 employees, while $21.88 \%$ of the companies had between 151 to 300 employees. 14.58\% of the companies had between 50 to 150 employees and $9.72 \%$ had less than 50 employees.

As for the aspect of respondents' position, 57.29\% held middle management post, $32.99 \%$ of Malaysian respondents held senior management posts, and this was followed by others positions at $9.72 \%$. Meanwhile, respondent holding current position (years) for more than 6 years was $47.92 \%$, the position between 1 to 3 years was $18.40 \%$, and the position held for less than 1 year was $10.76 \%$.

For the certification, some companies had more than one certification. $79.17 \%$ of the companies had ISO TS 16949 certification while $51.04 \%$ had ISO 14001 certification. $28.47 \%$ had ISO 9001:2008 certification while $19.44 \%$ had OHSAS 18001 certification. A few of the companies had won quality awards such as State Quality Award, Industrial Excellence Award, and Quality Management Excellence Award. This indicates that the companies had achieved a good performance as automotive suppliers.

\subsection{RESULTS AND DISCUSSION}

\section{Exploratory Factor Analysis (EFA)}

The data analysis started with EFA which was used to reduce the number of scale provided. The objectives of EFA are referred to accesses the construct validity of a test or instrument and analyze the relationship between variables (Williams et al., 2012).

\section{EFA on ISO 26000 Constructs}

EFA on ISO 26000 constructs for 10 items which described two constructs (recognizing social responsibility and stakeholder identification and engagement) was conducted on the random sample $(n=288)$ among Malaysian automotive suppliers. In Table 5, KMO and Bartlett's test for ISO 26000 constructs showed a value of 0.898 which was suitable for KMO measure of sampling adequacy.

Table 5 Result of KMO and Bartlett's test for ISO 26000 constructs

\begin{tabular}{lll}
\hline Kaiser-Meyer-Olkin Measure of Sampling Adequacy. & 0.898 \\
Bartlett's Test of Sphericity & Approx. Chi-Square & 1248.626 \\
& df & 45 \\
& Sig. & .000 \\
\hline
\end{tabular}

All factors contributed $61.321 \%$ from the total variance explained for ISO 26000 and a total of two components having Eigenvalues $>1$. Table 6 presents a cumulative percentage of total variance explained as $61.321 \%$. Thus, total variance explained for ISO 26000 were greater than $50 \%$ which was accepted.

Table 6 Results of total variance explained for ISO 26000 items

\begin{tabular}{|c|c|c|c|c|c|c|c|c|c|}
\hline \multirow{2}{*}{$\begin{array}{l}\mathrm{C} \\
\mathrm{o} \\
\mathrm{m}\end{array}$} & \multicolumn{3}{|c|}{ Initial Eigenvalues } & \multicolumn{3}{|c|}{$\begin{array}{l}\text { Extraction Sums of Squared } \\
\text { Loadings }\end{array}$} & \multirow{2}{*}{$\begin{array}{l}\text { Rotation } \\
\text { Loadings } \\
\text { Total }\end{array}$} & \multirow{2}{*}{$\begin{array}{l}\text { Sums of } \\
\% \text { of } \mathrm{Var}\end{array}$} & \multirow{2}{*}{$\begin{array}{l}\text { Squared } \\
\text { Cum\% }\end{array}$} \\
\hline & Total & $\%$ of $\operatorname{Var}$ & Cum \% & Total & $\begin{array}{l}\% \text { of } \\
\text { Var }\end{array}$ & Cum \% & & & \\
\hline 1 & 4.913 & 49.132 & 49.132 & 4.913 & 49.132 & 49.132 & 3.173 & 31.729 & 31.729 \\
\hline 2 & 1.219 & 12.189 & 61.321 & 1.219 & 12.189 & 61.321 & 2.959 & 29.592 & 61.321 \\
\hline
\end{tabular}


The first factor was made up of the five items from RSR including RSR1, RSR2, RSR3, RSR4, and RSR5. No items were suggested to be removed. The second factor was classified as SIE with five items namely SIE2, SIE3, SIE4, SIE5, and SIE6. One item for SIE1 was suggested to be removed. Thus, 10 items for ISO 26000 were applicable in this study.

\section{Confirmatory Factor Analysis (CFA)}

The data collected were tested for reliability and validity by using confirmatory factor analysis (CFA) to test the measurement model of ISO 26000. CFA was used to test the measurement model before starting the test of the structural model.

\section{ISO 26000 with Two Constructs}

Figure 1 presents the results of the CFA. $\chi 2$ as 78.421 (degree of freedom $=34, p<0.001$ ) and $\chi 2 /$ df was 2.306 , a value which was less than 3.0. The Goodness of Fit (GFI) was 0.949 and Adjusted Good of Fit (AGFI) was 0.917. The Comparative Fit Index (CFI) was 0.964 and Tucker Lewis Coefficient Index (TLI) was 0.952. The value of (RMSEA) was 0.067 less than 0.08 which displayed a good fit. Canonical correlations, rc (0.73) gave the value of less than 1.0, indicating that discriminant validity was acceptable. Therefore, two constructs were applicable to measure ISO 26000.

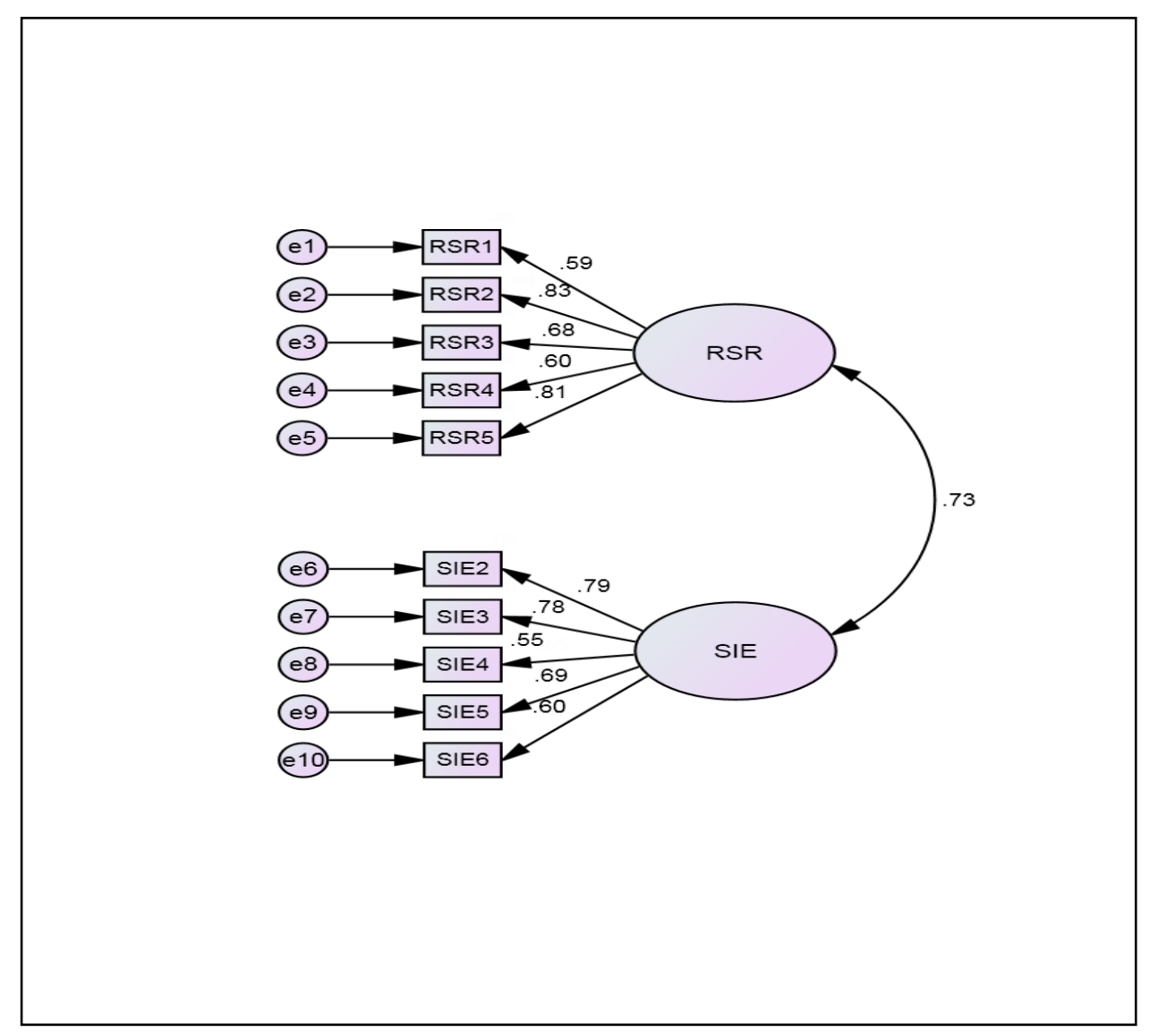

Figure 1 Path diagram for two constructs of ISO 26000 model

The model showed a good fit; all observed variables were significant at $\mathrm{p}<0.001$. Companies need to implement ISO 26000 in order to enhance the company's performance (Oladele, 2012; Fuzi et al., 2012; Habidin, 2014). In other words, ISO 26000 provides a positive impact on social and environmental aspects. According to finding by Girard and Sobczak (2012) and Fuzi et al. (2013), ISO 26000 is as the guideline in order to enhance the performance for Malaysian automotive suppliers. By adopting ISO 26000 constructs for Malaysian automotive suppliers, the companies have potential to improve the quality of company management. Thus, ISO 26000 constructs can be implemented in order to succeed and sustain social responsibility for Malaysian automotive suppliers.

\subsection{CONCLUSION}

In this study, two ISO 26000 constructs had been identified and assessed. The contribution of the research is not only limited for academic purposes but also for practitioners as well, especially for Malaysian automotive suppliers. The key contributions of this research are the development and verification of two ISO 26000 constructs by using the SEM technique. This study is to provide reliable and valid for 
instrument and structural relationship model for ISO 26000. Empirical test result showed that ISO 26000 consist of recognizing social responsibility and stakeholder identification and engagement. The final result of this study is reliable and valid in terms of decision-making process through ISO 26000 implementation for Malaysian automotive suppliers. This research has limitations as it has focused only on Malaysian automotive suppliers. Another limitation is the lack of literature on ISO 26000. The ISO 26000 are still limited in terms of literature in this research area, provided the opportunities and recommendations for future researchers to explore this research area in detail for ISO 26000 implementation. For future research, it is hoped that the structural relationship model between CSR practices, ISO 26000 , and CSRP can assist Malaysian automotive suppliers in order to enhance the quality of company management.

\section{References}

Abdullah, R., Lall, M. K., \& Tatsuo, K. (2008). Supplier Development Framework In The Malaysian Automotive Industry: Proton's Experience. International Journal of Economics and Management, 2(1), 29-58.

Bal, M., Bryde, D., Fearon, D., \& Ochieng, E. (2013). Stakeholder Engagement: Achieving Sustainability In The Construction Sector. Sustainability, 5(2), 695-710.

Balzarova, M. A., \& Castka, P. (2012). Stakeholders' Influence And Contribution To Social Standards Development: The Case Of Multiple Stakeholder Approach to ISO 26000 Development. Journal of Business Ethics, 111(2), 265-279

Barrantes, P. A. (2012) Examining The Relationship Between Employees' Perceptions Of And Attitudes Toward Corporate Social Responsibility And Organizational Identification (Doctoral Dissertation). The Florida State University.

Bottenfield, K. (2013) Examining The Construct Validity And Reliability Of Student Engagement Among Adult Student (Doctoral Dissertation). Iowa State University.

Brown, J. A., \& Forster, W. R. (2013). CSR And Stakeholder Theory: A Tale Of Adam Smith. Journal of Business Ethics, 112(2), 301-312.

Bustami, R., Na, D., Nasruddin, E., \& A'mmaari, S. R. (2013). Exploring ISO 26000 And Global Reporting Initiatives (GRI): A Neo- Institutional Analysis Of Two CSR Institutions. International Economics Letters, 2(2), 48-69.

Butler, J. B., Henderson, S. C., \& Raiborn, C. (2011). Sustainability And The Balanced Scorecard: Integrating Green Measures Into Business Reporting. Management Accounting Quarterly, 12(2), 1-10.

Canada, I. (2012). The Importance Of Stakeholder Engagement. Retrieved from http://www.ic.gc.ca/eic/site/csr-rse.nsf/eng/rs00139.html

Castka, P., \& Balzarova, M. A. (2007). A Critical Look On Quality Through CSR Lens: Key Challenges Stemming From The Development Of ISO 26000. International Journal of Quality \& Reliability Management, 24(7), 738-752

Dincer, B. (2011). Do The Shareholders Really Care About Corporate Social Responsibility? International Journal of Business and Social Science, 2(10), 71-76.

Donaldson, T., \& Preston, L. E. (1995). The Stakeholder Theory Of The Corporation: Concepts, Evidence, And Implications. Academy of Management Review, 20(1), $65-91$

Drost, E. A. (2011). Validity And Reliability In Social Science Research. Education Research and Perspectives, 38(1), $105-123$.

Ecologia. (2011). Handbook For Implementers Of ISO 26000. Retrieved from http://www.ecologia.org/isosr/ISO26000Handbook.html

Frost, R. (2009). Social Responsibility: ISO 26000. Executive Briefing on ISO 26000. ISO Management Systems Special Report, 9(5), 1-50.

Frost, R. (2009). Social Responsibility: ISO 26000. Executive Briefing on ISO 26000. ISO Management Systems Special Report, 9(5), 1-50.

Fuzi, N. M., Habidin, N. F., Desa, A. F. N. C., Zamri, F. I. M., \& Hibadullah, S. N. (2013). Corporate Social Responsibility Practices, ISO 26000 Efforts And CSR Performance In Malaysian Automotive Industry. International Journal of Managerial and Financial Accounting, 5(3), $277-293$.

Fuzi, N. M., Habidin, N. F., Hibadullah, S. N., Zamri, F. I. M., \& Desa, A. F. N. C. (2015). Critical Success Factors Of Corporate Social Responsibility Practices For The Malaysian Automotive Industry. International Journal of Critical Accounting, 7(2), 142-156.

Girard, C., \& Sobczak, A. (2012), Towards A Model Of Corporate And Social Stakeholder Engagement: Analyzing The Relations Between French Mutual Bank And Its Members. Journal of Business Ethics, 107(2), 215-225.

Greenwood, M. R. (2004). Stakeholder Engagement As Social (IR) Responsibility. Working Paper 1/04, Australian and New Zealand Academy of Management 17th Annual Conference 2-5 December 2003, Fremantle, Western Australia.

Habidin, N. F. (2012). Structural Analysis And Tool For Lean Six Sigma, Strategic Control Systems And Organizational Performance. Thesis of Engineering Doctorate (Engineering Business Management), UTM Razak School of Engineering and Advanced Technology, University Teknologi Malaysia.

Habidin, N. F., \& Yusof, S. M. (2012). Relationship Between Lean Six Sigma, Environmental Management Systems, And Organizational Performance In The Malaysian Automotive Industry. International Journal of Automotive Technology, 13(7), 1119-1125.

Habidin, N. F., \& Yusof, S. M. (2013). Critical Success Factors Of Lean Six Sigma For Malaysian Automotive Industry. International Journal of Lean Six Sigma, $4(1), 60-82$.

Habidin, N. F., Fuzi, N. M., Desa, A. F. N. C., Hibadullah, S. N., \& Zamri, F. I. M. (2014). ISO 26000 Efforts And Corporate Social Responsibility Performance In Malaysian Automotive Industry. International Journal of Business Excellence, 7(4), 515-529.

Habidin, N. F., Zubir, A. F. M., Conding, J., Jaya, N. A. S. L., \& Hashim, S. (2013). Sustainable Manufacturing Practices, Sustaining Lean Improvements And Sustainable Performance In Malaysian Automotive Industry. International Journal of World Review of Entrepreneurship, Management and Sustainable Development, 9(4), 444-459.

Hahn, R. (2012). ISO 26000 And The Standardization Of Strategic Management Processes For Sustainability And Corporate Social Responsibility. Business Strategy and the Environmemt, 22(7), 442-455.

Hair, J. F., Ringle, C. M., \& Sarstedt, M. (2011). PLS-SEM: Indeed A Silver Bullet. Journal of Marketing Theory and Practice, 19(2), 139-151.

Harrison, J., Rouse, P., \& Villiers, C. J. D. (2012). Accountability And Performance Measurement: A Stakeholder Perspective. The Business and Economics Research Journal, 5(2), 243-258.

Hashim, S., Habidin, N. F., Conding, J., Zubir, A. F. M., and Jaya, N. A. S. L. (2012). Total productive maintenance kaizen event, innovation performance in Malaysian automotive industry. International Journal of Physical and Social Sciences, 3(1), 45-64.

Hibadullah, S. N., Habidin, N. F., Zamri, F. I. M, Fuzi, N. M., \& Desa, A. F. N. C. (2013). The Integrated Between Lean Manufacturing Practices And ISO 14001 Efforts In Malaysian Automotive Industry. Journal of Applied Science and Research, 1(1), 17-27.

Hibadullah, S. N., Habidin, N. F., Zamri, F. I. M, Fuzi, N. M., \& Desa, A. F. N. C. (2014). Critical Success Factors Of Lean Manufacturing Practices For The Malaysian Automotive Manufacturers. International Journal of Quality and Innovation, 2(3/4), 256-271.

Hoivik, H. V. W. (2011). Using ISO 26000 to Implement A Learning And Knowledge Creating Process In Two SMES. Working Paper No. 26/11, Institute for Research in Economics and Business Administration.

Huijstee, M. V., and Glasbergen, P. (2008). The Practice Of Stakeholder Dialogue Between Multinationals And NGOS. Retrieved from http://www.unpop.nl/inhoud/artikelen/

ISO 26000: 2010 (E). Guidance on social responsibility. International Standard ISO 26000.

Jain, P. M., \& Shandliya, V. K. (2013). A Survey Paper On Comparative Study Between Principal Component Analysis (PCA) And Exploratory Factor Analysis (EFA). International Journal of Computer Science and Applications, 6(2), 373-375.

Jaya, N.A.S.L., Habidin, N.F., Zubir, A.F.M., Conding, J., \& Hashim, S. (2012). Exploring Information Manufacturing Sharing And Supply Chain Performance: Based on Malaysian Automotive Industry. IOSR Journal of Engineering, 2(7), 41-48.

Kanokporn, T., Natcha, T., \& Damrong, T. (2013). Green Industry System Development By Applying International Standards. Journal of Advanced Management Science, 1(1), 96-101.

Kelly, M., \& Bather, A. (2009). Corporate Social Responsibility And The Teaching Of Management Accounting. Philosophy of Management, 8(1), 15-26. 
Kosi, K., \& Harazin, P. (2011). Performance Evaluation Of Corporate Social Responsibility According To The Logic Of ISO 26000. Regional and Business Studies, 3(1), 739-749.

Mainardes, E. W., Alves, H., \& Raposo, M. (2011). Stakeholder Theory: Issues To Resolve. Management Decision, 49(2), 226-252.

Mckelvey, H. (2007). ISO 26000: How the New Standard for Social Responsibility from the International Standards Organization Will Impact the Role of the Management Consultant and the Management Consulting Industry (Master's Thesis). Faculty of Commerce, Saint Mary's University.

Merz, S. K. (2011). ISO 26000 Guidance On Social Responsibility. Retrieved from http://www.globalskm.com/Insights/Achieve-Magazine/Issue2-2011/article7.aspx

Min, L. A. (2010). The Perception of Ethics and Social Responsibility of Malaysian International Chamber of Commerce and Industry Corporate Members in Relation to ISO 26000-Social Responsibility Adoption (Doctoral Dissertation). University Utara Malaysia, Kedah.

Ministry of International Trade and Industry. (2014). National Automotive Policy (NAP). Retrieved from http://www.miti.gov.my/

Moonsamy, V., \& Singh, S. (2012). A 21st Century Framework For Quality Management. African Journal of Business Management, 6(45), 11231-11242.

Nisipeanu, S., Damian, G. S., Carţana, C., Bantasa, D., \& Serafim, A. (2011). CSR Contribution To Sustainable Development In The Energetic Sector. Journal of Sustainable Energy, 2(2), 97-102.

Oladele, J. A. (2012). Survey Of Corporate Social Responsibility Practices In Nigerian Manufacturing Sector. International Journal of Research Studies in Management, 1(1), 1-10.

Peloza, J., \& Papania, L. (2008). The Missing Link Between Corporate Social Responsibility And Financial Performance: Stakeholder Salience And Identification. Corporate Reputation Review, 11(2), 169-181.

Perera, O. (2009). ISO 26000 - Social Responsibility SMES, ISO 26000 And Social Responsibility. Special Report, ISO Management Systems. Retrieved from http://www.iisd.org/publications/pub.aspx?id=1199

Pojasek, R. B. (2011). Pojasek, R. B. (2011). ISO 26000 Guidance On Social Responsibility. Environmental Quality Management, 20 (3), 85-93.

Roberts, J. M. (2010). How Corporate Social Responsibility (ISO 26000) Mandates Undermine Free Markets. Retrieved from http://www.heritage.org/research/reports/

Schwartz, B., \& Tilling, K. (2009). ISO-lating' Corporate Social Responsibility In The Organizational Context: A Dissenting Interpretation Of ISO 26000. Corporate Social Responsibility and Environmental Management, 16(5), 289-299.

Sedani, C. M., \& Lakhe, R. R. (2011). ISO Certification And Business Performance: Empirical Findings Of Indian SMEs. International Journal of Business Excellence, 4(6), 715-730.

Singh, R. (2009). Does My Structural Model Represent The Real Phenomenon?: A Review Of The Appropriate Use Of Structural Equation Modelling (SEM) Model Fit Indices. The Marketing Review, 9(3), 199-212.

Sitnikov, C. S., \& Bocean, C. G. (2012). Corporate Social Responsibility Through The Lens Of ISO Standards. Business Excellence and Management, 2(4), 56-66.

Sofia, P. (2010). Identification of the Main Environmental Challenges in A Sustainability Perspective for the Automobile Industry (Master's Thesis). Chalmers University Of Technology, Sweden.

Sully, R. (2012). ISO 26000: The Business Guide To The New Standard On Social Responsibility. Impact Assessment and Project Appraisal, $30(3), 214-215$.

Suntory, G. (2012). Stakeholder Engagement. Retrieved from http://www.suntory.com/csr/

Sweeney, L. (2009). A Study of Current Practice of Corporate Social Responsibility (CSR) and an Examination of the Relationship between CSR and Financial Performance using Structural Equation Modeling (SEM) (Doctoral Dissertation), Dublin Institute of Technology.

Tavakol, M., \& Dennick, R. (2011). Making Sense Of Cronbach's Alpha. International Journal of Medical Education, 2 (2), 53-55.

Vazquez, L. G., \& White, R. G. (2012). Can Mining Be Sustainable? ISO 26000 SR For Responsible Exploration And Sustainable Mining. Ideas CONCYTEG, 7(81), 323-341.

Virtanen, A. A. (2013). Managerial Perceptions on Corporate Social Responsibility: A Transatlantic Comparison between Forest Products Companies in Europe and North America (Master's Thesis), Department of Forest Sciences, University of Helsinki.

Ward, H. (2012). ISO 26000 And Global Governance For Sustainable Development. Retrieved from http://pubs.iied.org

Webb, K. (2012). ISO 26000: Bridging The Public/Private Divide In Transnational Business Governance Interactions. Research Paper, 8(5), $2-29$.

Weber, T. (2012). How ISO standards support global car industry. Available: http://www.iso.org/iso/cars_compilation

Weinestedt, H. (2009). Stakeholder Analysis as a Tool for Working with Social Responsibility. Developing a Stakeholder Analysis Method for ISO 26000 (Master's Thesis). Stockholm Resilience Centre, Stockholm University.

Williams, B., Brown, T., \& Onsman, A. (2012). Exploratory Factor Analysis: A Five-step Guide For Novices. Australasian Journal of Paramedicine, 8(3), 1-13.

Zgodavova, K., \& Bober, P. (2012). An Innovative Approach To The Integrated Management System Development: Simpro-Ims Web Based Environment. Quality Innovation Prosperity, XVI(2), 59-70.

Zhang, W. (2012). Gap Analysis of ISO 26000 in Two Atlas Copco Companies in China (Master's Thesis), Royal Institute of Technology.

Zubir, A. F. M., Habidin, N. F., Conding, J., Jaya, N. A. S. L., and Hashim, S. (2012). The Development Of Sustainable Manufacturing Practices And Sustainable Performance In Malaysian Automotive Industry. Journal of Economics and Sustainable Development, 3(7), $130-138$. 